\title{
The distribution of the freshwater crab Fredius reflexifrons (Ortmann, 1897) (Brachyura, Pseudothelphusidae) in an Environmental Protection Area of the Planalto da Ibiapaba, Northeastern Brazil
}

\author{
LIVANIO C. DOS SANTOS, WHANDENSON M. DO NASCIMENTO, \\ HELAINE S. MATOS, ALLYSSON P. PINHEIRO \& JOSÉ R.F. SILVA
}

\begin{abstract}
Freshwater crabs are important components of aquatic ecosystems; however, their distributions are restricted because of characteristics of their life history, which hinder conservation strategies. Fredius reflexifrons is a widely distributed freshwater crab of the Amazon basin with relictual occurrences in small wetlands on the Planalto da Ibiapaba in Northeastern Brazil. Habitat degradation, destruction of forest patches, channeling of water bodies, and the use of land for legume cropping can seriously impact the species by leading to the extinction of its relic populations, which have limited distributions in the Área de Proteção Ambiental (APA; Environmental Protection Area) Bica do Ipu of the Planalto da Ibiapaba. The objectives of this study were to assess the distribution of F. reflexifrons in APA Bica do Ipu, identify the main impacts from anthropic activities, suggest potential actions to mitigate these impacts, besides providing recommendations for the expansion of the APA. Fredius reflexifrons was recorded in eleven sites in the Planalto da Ibiapaba, of which nine are new records and five are not located within the APA. These findings evidence the need of expanding the APA to encompass the newly known distribution of $F$. reflexifrons in order to assure its protection.
\end{abstract}

Key words: Brachyura, conservation unit, Northeastern semiarid region, relictual distribution.

\section{INTRODUCTION}

The family Pseudothelphusidae encompasses primary freshwater crabs exclusive to the Neotropical Region that complete their entire life cycle independently of salt water (Cumberlidge et al. 2014, Yeo et al. 2008). Primary freshwater crabs have direct development, by which juveniles hatch from eggs as small versions of the adults with the ability to breath out of water, and the adult females perform parental care (Vogt 2013, 2016). The distribution of species of the Pseudothelphusidae are strongly influenced by climatic conditions and local topography (Fang et al. 2013).

Among species of the Pseudothelphusidae, Fredius reflexifrons (Ortmann 1897) is widely distributed in the Amazon basin and in some coastal river basins of northern countries in South America (Magalhães 2003, Cumberlidge et al. 2014). Magalhães et al. (2005) expanded the distribution of the species with records from the Planalto da Ibiapaba in Northeastern Brazil. The occurrence of this crab in the 
Northeastern Region of Brazil raises questions about its dispersion routes presenting disjunct distribution from its congeners occurring in the Amazon basin.

Considered as relict (Magalhães et al. 2005), the populations of $F$. reflexifrons on the Planalto da Ibiapaba have a high degree of endemism and a low dispersion index, which limit conservation strategies (Yeo et al. 2008). Degradation of forest patches and water sources, as well as the use of land for agriculture, in areas of occurrence of F. reflexifrons, are factors that can lead to local extinction of these crustaceans.

Most species of endangered freshwater crabs are found in places of intense deforestation with altered patterns of water sources and pollution (Yeo et al. 2008). This situation, intensified by the low rate of dispersal of these organisms (Vogt 2013), may accelerate the local extinction of populations. Conservation actions for members of the family Pseudothelphusidae are scarce or absent, especially for $F$. reflexifrons since there are no estimates of population structure and biology for this species up to date (Magalhães 2016). This fact raises concern, because the sites of occurrence of this species are under anthropic impacts, influencing its population structure.

The objectives of the present study were to assess the distribution of the Fredius reflexifrons, on the Planalto da Ibiapaba in the Área de Proteção Ambiental - APA (Environmental Protection Area) Bica do Ipu, and to identify the main impacts caused by anthropic activities. Socio-environmental measures for conservation of the species are also discussed.

\section{MATERIAL AND METHODS}

\section{Study area}

The study took place in APA Bica do Ipu, located on the Planalto da Ibiapaba within the municipality of Ipu, state of Ceará, Brazil.
Encompassing 3,484.66 hectares, APA Bica do Ipu is a conservation unit for sustainable use with hillside and areas of high elevation (SEMA 2013). This conservation unit was created to promote awareness and protection of the local fauna and flora, and encourage sustainable use of its natural resources by the local community (CEARÁ 1999).

\section{Field procedures}

Active searches were conducted in wetlands, streams, and muddy sites. Diurnal active searches of 40 minutes were performed in August and October 2017. Burrows were used as an indication of presence of crabs and were checked for the presence or absence of $F$. reflexifrons.

Temperature, humidity, elevation, and geographic coordinates were measured in every site. Impacts from anthropic activities, such as deforestation of riparian forest and wetlands, the presence of solid waste, legume cropping, and the channeling of water bodies were recorded when observed.

Captured specimens were stored in plastic bags with crushed ice and refrigerated. Afterwards, they were preserved in 70\% alcohol and taken to the Laboratório de Crustáceos do Semiárido of the Universidade Regional do Cariri - LACRUSE / URCA. In the laboratory, species identification was confirmed using the dichotomous key of Magalhães (2003). The specimens were deposited in the LACRUSE carcinological collection.

The parameters Extent of Occurrence (EOO) and Area of Occupancy (AOO) - which refer to the size of the geographic range and the area within the EOO occupied by a species, respectively (Bachman et al. 2011) - were determined for the specimens found in the sites of the expeditions conducted in Planalto da Ibiapaba. The geographic coordinates of the distribution 
of the species were used to estimate the EOO and $\mathrm{AOO}$ by overlapping a grid of $2 \times 2 \mathrm{~km}$ and summing the area of occupied cells using the software geoCAT (http://geocat.kew.org).

\section{RESULTS}

The occurrence of F. reflexifrons was confirmed in the 11 sites surveyed (Table I).

Among the 11 sites surveyed, Santa Cruz I and II (water sources), Taperinha (water source), Riacho da Taperinha and Riacho da Santa Luzia, are outside the limits of APA Bica do Ipu and are less environmentally impacted than the localities within the APA.

The results showed that the areas where individuals of $F$. reflexifrons were found have the presence of a water source, are at high elevations, and have high humidity. All collecting sites (Figure 1) were under the influence of some type of anthropic action, such as the presence of solid waste, deforestation of the original vegetation for legume and fruits crops (e.g., banana), and the channeling of water sources for domestic use, crop irrigation, and animal watering.

The EOO for F. reflexifrons was estimated at $3.240 \mathrm{~km}^{2}$ while the AOO was estimated at 24.000 $\mathrm{km}^{2}$. Thus, the AOO for F. reflexifrons appears to have been reduced in the Planalto da Ibiapaba.

\section{DISCUSSION}

The relic population of $F$. reflexifrons on the Planalto da Ibiapaba is more widely distributed than previously known (Magalhães et al. 2005). However, the environmental degradation observed in the sites surveyed in this study, like channeling of water bodies for irrigation, can lead to extinction of local populations. Although individuals of $F$. reflexifrons are semi-terrestrial, and are capable of breathing out of the water, they still require moisture for survival. Thus, the channeling of water bodies on the Planalto da Ibiapaba has the potential to drastically reduce the size of the populations dwelling in the sampled sites.

The distribution of $F$. reflexifrons previously encompassed only two records in the APA Bica do Ipu: Sítio Caranguejo and Sítio Santa Cruz I (Magalhães et al. 2005). Thus, the present study records nine additional sites. One of the most important actions for conservation of a species is to identify areas of occurrence in order to

\section{Table I. Localities surveyed for Fredius reflexifrons (Ortmann, 1897) in Planalto da Ibiapaba, Northeastern Brazil, with their respective elevations and anthropic impacts.}

\begin{tabular}{|c|c|c|}
\hline Locality & Elevation (m) & Impacts \\
\hline $\begin{array}{l}\text { 1- Gameleira } \\
\text { water grove }\end{array}$ & 664 & water piping \\
\hline $\begin{array}{l}\text { 2- Gameleira } \\
\text { backyard }\end{array}$ & 665 & $\begin{array}{c}\text { water piping, } \\
\text { banana } \\
\text { plantation }\end{array}$ \\
\hline $\begin{array}{l}\text { 3- Sitio Ipuçaba } \\
\text { (waterfall) }\end{array}$ & 651 & water piping \\
\hline $\begin{array}{l}\text { 4- Sitio Ipuçaba } \\
\text { (water source) }\end{array}$ & 696 & water piping \\
\hline $\begin{array}{l}\text { 5- Cinta (water } \\
\text { source) }\end{array}$ & 717 & plantation \\
\hline $\begin{array}{c}\text { 6- Sitio } \\
\text { Caranguejo (water } \\
\text { source) }\end{array}$ & 729 & $\begin{array}{c}\text { legume } \\
\text { cropping, } \\
\text { banana } \\
\text { plantation, } \\
\text { water piping }\end{array}$ \\
\hline $\begin{array}{l}\text { 7- Santa Cruz I } \\
\text { (water source) }\end{array}$ & 782 & $\begin{array}{c}\text { banana } \\
\text { plantation, } \\
\text { water piping }\end{array}$ \\
\hline $\begin{array}{l}\text { 8- Santa Cruz II } \\
\text { (water source) }\end{array}$ & 698 & well preserved \\
\hline $\begin{array}{l}\text { 9- Taperinha } \\
\text { (water source) }\end{array}$ & 786 & well preserved \\
\hline $\begin{array}{l}\text { 10- Taperinha } \\
\text { stream }\end{array}$ & 759 & well preserved \\
\hline $\begin{array}{l}\text { 11- Santa Luzia } \\
\text { stream }\end{array}$ & 542 & well preserved \\
\hline
\end{tabular}


guarantee its protection (Dalu et al. 2017). The study of the characteristics of the habitat where these freshwater crustaceans are found can help the development of conservation strategies for threatened populations (Dalu et al. 2016). Thus, it is necessary to carefully conserve and manage habitat heterogeneity so that the survival of these crabs is assured (Chua et al. 2015).

Another factor to be considered is that APA Bica do Ipu does not include all the sites of occurrence of $F$. reflexifrons recorded in the present study (i.e., Santa Cruz I and II (water sources), Taperinha (water source)), Riacho da Taperinha and Riacho da Santa Luzia), which further weakens the conservation actions for these populations. These sites should be included within the APA because they are better preserved, which would enable a proper management of the populations in their occurrence area.

It was not possible to capture crabs in every burrow found in some sites due to the difficulty of excavating them from their depths in dry, stony soil. This behavior may reflect a mechanism used by this crustacean to shelter themselves in the terminal portion of their burrows to prevent dehydration during periods of drought and to avoid potential predators (Bliss 1968, Atkinson \& Taylor 1988).

\section{Distribution of Fredius reflexifrons on the Ibiapaba Plateau}

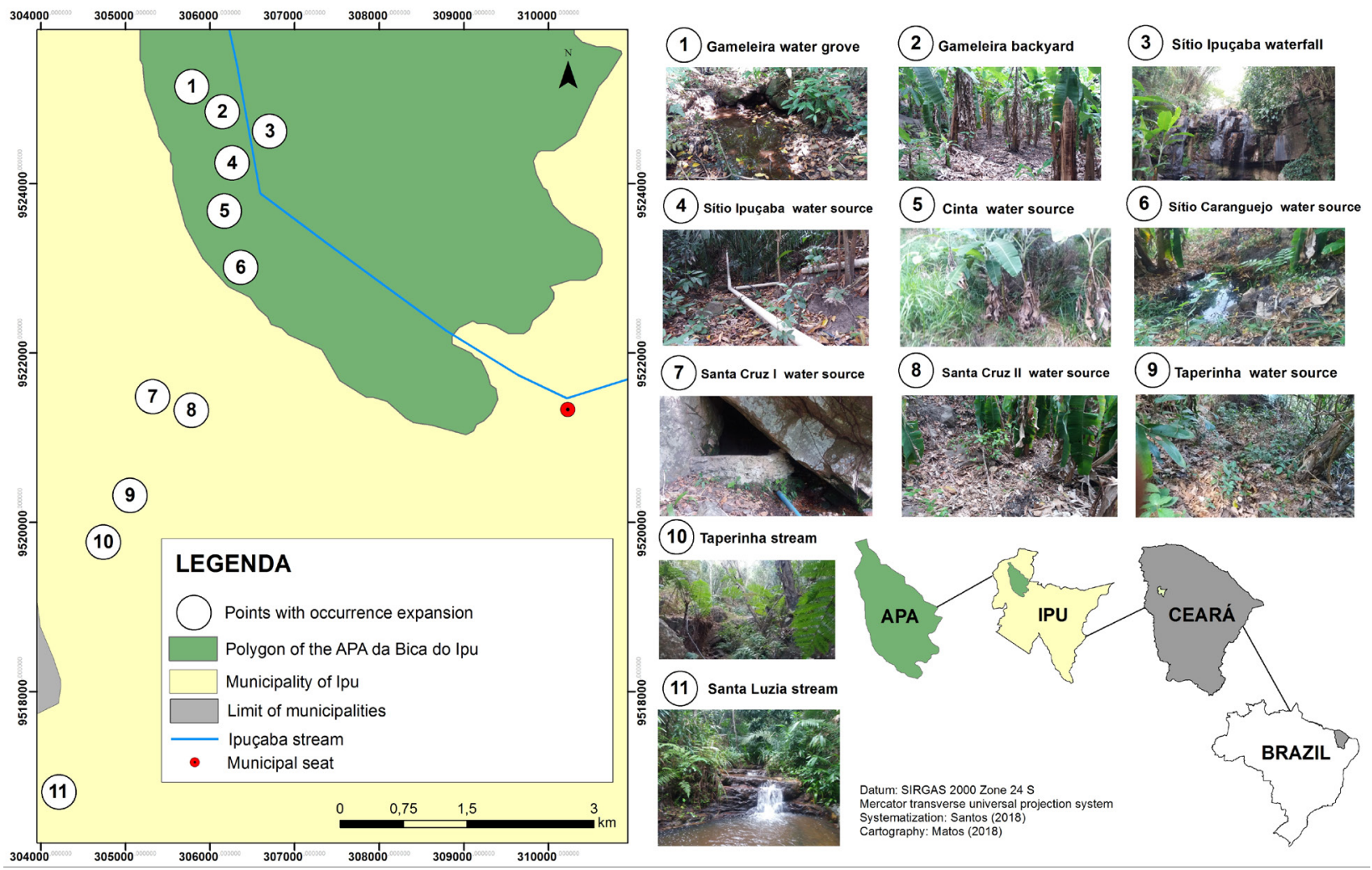

Figure 1. Sites with occurrence of Fredius reflexifrons on the Planalto da Ibiapaba. 
Since anthropic influences are everywhere and almost impossible to avoid (Cumberlidge et al. 2009), an alternative for minimizing threats would be the partial channeling of water sources. Such practice would provide water flow in the soil of the areas where the species is known to occur, especially during the dry season (June to December) (IPECE 2017), and thus maintaining a suitable microclimate.

Freshwater crabs comprise a critically endangered fauna. Environmental authorities need to be cognizant of this (Wehrtmann et al. 2016) and, with the help of specialists, seek strategies for their conservation. The conservation of forest patches, river springs, and water bodies in the APA Bica do Ipu can help to prevent local extinctions of $F$. reflexifrons, as well as allow the species to thrive.

The inclusion of the local community by means of environmental education is another strong tool for the conservation of this crustacean. Moreover, future studies on its ecology, reproductive biology, and population structure and dynamics are essential for understanding the status of the relic populations of the crab on the Planalto da Ibiapaba. Lastly, expansion of APA Bica do Ipu encompassing all sites of occurrence of $F$. reflexifrons in the region is needed.

Although Cumberlidge (2008) considers populations of $F$. reflexifrons to be stable, the AOO for populations from Planalto da Ibiapaba indicates that they should be considered Endangered (EN), whereas at the local scale the EOO indicates that the species is critically endangered or threatened. In addition, the unabated advancement of forest degradation from anthropogenic activities will likely lead to habitat loss, and thus to potential local extinction of these small relictual populations of F. reflexifrons in the APA Bica do Ipu of the Planalto da Ibiapaba.

\section{Acknowledgments}

We thank the Instituto Chico Mendes de Conservação da Biodiversidade (ICMBio) and the Secretaria de Meio Ambiente do Ceará (SEMA) for the collection licenses $n^{\circ}$. 60512-1 and 16/2017. This study was partially financed by the Coordenação de Aperfeiçoamento de Pessoal de Nivel Superior - Brazil (CAPES) - Finance Code 001.

\section{REFERENCES}

ATKINSON RJA \& TAYLOR AC. 1988. Physiological ecology of burrowing decapods. Symp Zool Soc London 59: 201-226.

BACHMAN S, MOAT J, HILL AW, DE TORRE J \& SCOTT B. 2011. Supporting Red List threat assessments with GeoCAT: geospatial conservation assessment tool. ZooKeys 150: 117.

BLISS D. 1968. Transition from water to land in decapod crustaceans. Am Zool 8: 355-392.

CEARA. 1999. DECRETO №25.354 dispõe sobre a criação da Área de Proteção Ambiental da Bica do Ipu. DOE 243: 6-11.

CHUA KW, NG DJ, ZENG Y \& YEO DC. 2015. Habitat characteristics of tropical rainforest freshwater crabs (Decapoda: Brachyura: Potamidae, Gecarcinucidae) in Singapore. J Crustacean Biol 35: 533-539.

CUMBERLIDGE N. 2008. Fredius reflexifrons. The IUCN Red List of Threatened Species 2008: e.T135127A4064229. http:// dx.doi.org/10.2305/IUCN.UK.2008.RLTS.T135127A4064229. en. Downloaded on 12 July, 2018.

CUMBERLIDGE N, ALVAREZ F \& VILLALOBOS JL. 2014. Results of the global conservation assessment of the freshwater crabs (Brachyura, Pseudothelphusidae and Trichodactylidae): The Neotropical region, with an update on diversity. Zookeys 457: 133-157.

CUMBERLIDGE N, NG PK, YEO DC, MAGALHÃES C, CAMPOS MR, ALVAREZ F \& CLOTILDE-BA FL. 2009. Freshwater crabs and the biodiversity crisis: importance, threats, status, and conservation challenges. Biol Conserv 142: 1665-1673.

CUMBERLIDGE N, NG PK, YEO DC, NARUSE T, MEYER KS \& ESSER, LJ. 2011. Diversity, endemism and conservation of the freshwater crabs of China (Brachyura: Potamidae and Gecarcinucidae). Integrative Zoology 6: 45-55.

DALU MT, WASSERMAN RJ \& DALU T. 2017. Can Potamonautids be used as umbrella invertebrate species for conservation: Identifying opportunities and challenges related to community sustainable livelihoods. Phy Chem Earth 101: 52-58.

DALU T, SACHIKONYE MT, ALEXANDER ME, DUBE T, FRONEMAN WP, MANUNGO KI \& WASSERMAN RJ. 2016. Ecological assessment 
of two species of potamonautid freshwater crabs from the eastern highlands of Zimbabwe, with implications for their conservation. PLOS ONE 11: e0145923.

FANG F, SUN H, ZHAO Q, LIN C, SUN Y, GAO W \& LIU N. 2013. Patterns of diversity, areas of endemism, and multiple glacial refuges for freshwater crabs of the genus Sinopotamon in China (Decapoda: Brachyura: Potamidae). PLoS ONE 8: 53143.

GBIF.org (23rd May 2018) GBIF Occurrence Download. Available at: https://doi.org/10.15468/dl.7zj0zo

IPECE - INSTITUTO DE PESQUISA E ESTRATÉGIA ECONÔMICA DO CEARÁ. 2017. Perfil Básico Municipal Ipu. Disponível em: https://www.ipece.ce.gov.br/ Acessado em: May 2018.

MAGALHÃES C. 2003. Famílias Pseudothelphusidae e Trichodactylidae. In: Melo GAS (Ed), Manual de Identificação dos Crustáceos Decápodos de Água Doce Brasileiros, São Paulo: Editora Loyola, p. 143-287.

MAGALHÃES C. 2016. Avaliação dos Pseudotelfusídeos (Decapoda: Pseudotelphusidae). In: Pinheiro MAA and Boos H (Eds), Livro Vermelho dos Crustáceos do Brasil: Avaliação 2010-2014, Porto Alegre: Sociedade Brasileira de Carcinologia, Porto Alegre, Brasil, p. 441-458.

MAGALHÃES C, ABRUNHOSA FA, PEREIRA MDO \& MELO MA. 2005. New records of Fredius denticulatus (H. Milne-Edwards, 1853) and F. reflexifrons (Ortmann, 1897), and the eastern limits of the distribution of pseudothelphusid crabs (Crustacea: Decapoda) in Brazil. Acta Amazon 35: 93-96.

ORTMANN AE. 1897. Carcinologische Studien. Zoologische Jahrbücher, Abtheilung für Systematik, Geographie und Biologie der Thiere, 10: 258-372.

SEMA. 2013. Área de Proteção Ambiental da Bica do Ipu.Disponível em: http://www.sema.ce.gov.br/index. php?option=com_content\&view=article \&id=43665. Acessado em: Maio 2018.

VOGT G. 2013. Abbreviation of larval development and extension of brood care as key features of the evolution of freshwater Decapoda. Biol Rev 88: 81-116.

VOGT G. 2016. Structural specialties, curiosities, and recordbreaking features of crustacean reproduction. J Morphol 277: 1399-1422.

WEHRTMANN IS, MAGALHÃES C \& OROZCO MN. 2016. The primary freshwater crabs of Guatemala (Decapoda: Brachyura: Pseudothelphusidae), with comments on their conservation status. J Crustacean Biol 36: 776-784.

YEO DC, NG PK, CUMBERLIDGE N, MAGALHAES C, DANIELS SR \& CAMPOS MR. 2008. Global diversity of crabs (Crustacea: Decapoda: Brachyura) in freshwater. Hydrobiologia 595: 275-286.

\section{How to cite}

ANTOS LC, NASCIMENTO WM, MATOS HS, PINHEIRO AP \& SILVA JRF. 2020. The distribution of the freshwater crab FFredius reflexifrons (Ortmann, 1897) (Brachyura, Pseudothelphusidae) in an Environmental Protection Area of the Planalto da Ibiapaba, Northeastern Brazil. An Acad Bras Cienc 92: e20180814. DOI 10.1590/0001-3765202020180814.

manuscript received on August 7, 2018; accepted

for publication on December 27, 2018

\section{LIVANIO C. DOS SANTOS ${ }^{1}$}

https://orcid.org/0000-0001-7084-5146

\section{WHANDENSON M. DO NASCIMENTO ${ }^{2}$}

https://orcid.org/0000-0002-4304-0980

\section{HELAINE S. MATOS ${ }^{3}$}

https://orcid.org/0000-0002-5351-1547

\section{ALLYSSON P. PINHEIRO}

https://orcid.org/0000-0003-1565-6371

\section{JOSÉ R.F. SILVA ${ }^{1}$}

https://orcid.org/0000-0002-6878-5516

${ }^{1}$ Programa de Pós-Graduação em Ecologia e Recursos Naturais, Departamento de Biologia, Universidade Federal do Ceará, Av. Mister Hull, s/n, 60455-760 Fortaleza, CE, Brazil

${ }^{2}$ Programa de Pós-Graduação em Bioprospecção Molecular, Departamento de Biologia, Universidade Regional do Cariri, Rua Coronel Antônio Luiz, 1161, Pimenta, 63105-010 Crato, CE, Brazil

${ }^{3}$ Programa de Pós-Graduação em Geografia, Departamento de Geografia Universidade Federal do Ceará, Av. Mister Hull, s/n, 60455-760 Fortaleza, CE, Brazil

Correspondence to: Livanio Cruz dos Santos

E-mail:santos.bio.79@gmail.com

\section{Author contributions}

LCS, WMN, HSM performed the fieldwork; LCS and WMN performed analysis statistics and tabulated the data; HSM performed the species distribution map and to critical reading of the manuscript. APP and JRFS revised and reviewed the manuscript and contributed to critical reading of the manuscript. All authors took part on the preparation, revised and approved the final version of the manuscript.

\section{(cc) BY}

